\title{
HIV-Related Risk Behaviors Among Male High School Students Who Had Sexual Contact with Males — 17 Large Urban School Districts, United States, 2009-2013
}

\author{
Laura Kann, $\mathrm{PhD}^{1}$; Emily O’Malley Olsen, $\mathrm{MSPH}^{1}$; Steve Kinchen ${ }^{1}$; Elana Morris, $\mathrm{MPH}^{2}$; Richard J. Wolitski, $\mathrm{PhD}^{3}$
}

Young persons aged 13-24 years accounted for an estimated $22 \%$ of all new diagnoses of human immunodeficiency virus (HIV) infection in the United States in 2014. Most new HIV diagnoses among youths occur among males who have sex with males (MSM). Among all MSM, young black MSM accounted for the largest number of new HIV diagnoses in 2014 (1). To determine whether the prevalence of HIV-related risk behaviors among black male high school students who had sexual contact with males differed from the prevalence among white and Hispanic male students who had sexual contact with males, potentially contributing to the racial/ethnic disparities in new HIV diagnoses, CDC analyzed data from Youth Risk Behavior Surveys conducted by 17 large urban school districts during 2009-2013. Although other studies have examined HIV-related risk behaviors among MSM $(2,3)$, less is known about MSM aged $<18$ years. Black male students who had sexual contact with males had a lower or similar prevalence of most HIV-related risk behaviors than did white and Hispanic male students who had sexual contact with males. These findings highlight the need to increase access to effective HIV prevention strategies for all young MSM.

Data from 32 Youth Risk Behavior Surveys conducted by 17 large urban school districts* during 2009-2013 were combined. In each survey in each district, a two-stage cluster sample design was used to produce representative samples of public school ${ }^{\dagger}$ students in grades 9-12. In the first sampling stage, in four of the districts, schools with any of grades 9-12 were sampled with the probability of selection proportional to school enrollment size; in the remaining 13 districts, all schools with any of grades 9-12 were sampled. In the second sampling stage, in 16 districts, classes from either a required subject (e.g., English or social studies) or a required period (e.g., homeroom or second period) were sampled randomly and all students in the sampled classes were eligible to participate. In one district all students were eligible to participate. School

\footnotetext{
* Located in Baltimore, Maryland (2013); Boston, Massachusetts (2009, 2011, 2013); Broward County, Florida (2013); Chicago, Illinois (2009, 2011, 2013); Detroit, Michigan (2011, 2013); District of Columbia (2013); Houston, Texas (2011, 2013); Los Angeles, California (2009, 2011, 2013); Memphis, Tennessee (2013); Milwaukee, Wisconsin (2009, 2011, 2013); New York City, New York (2009, 2011, 2013); Orange County, Florida (2013); Palm Beach, Florida (2013); Philadelphia, Pennsylvania (2013); San Diego, California (2011, 2013); San Francisco, California $(2011,2013)$; and Seattle, Washington $(2011,2013)$.

$\dagger$ Includes regular public schools but might also include charter schools and public alternative, special education, or vocational schools.
}

response rates ranged from $84 \%$ to $100 \%$, student response rates ranged from $66 \%$ to $90 \%$, overall response rates ${ }^{\S}$ ranged from $66 \%$ to $90 \%$, and total sample sizes ranged from 1,013 to 11,887 . Data from each survey were weighted to provide large urban school district-level estimates, and statistical software was used to account for the complex sample designs during analyses. Data are presented for non-Hispanic black (black), non-Hispanic white (white), and Hispanic male students only. Pairwise t-tests were used to determine statistically significant $(\mathrm{p}<0.05)$ differences among subgroups.

Survey procedures were designed to protect students' privacy by allowing anonymous and voluntary participation. Local parental permission procedures were followed before survey administration. Students completed the self-administered questionnaire during one class period and recorded their responses directly on a computer-scannable booklet or answer sheet. Each district's questionnaire included the following question to ascertain the sex of the respondent's sexual contacts: "During your life, with whom have you had sexual contact?" No definition was provided for sexual contact. The four possible response options were, "I have never had sexual contact"; "females"; "males"; and "females and males." This report describes 17 risk behaviors related directly or indirectly to HIV transmission among male students in grades 9-12 who indicated they had sexual contact with only males or with both males and females (i.e., male students who had sexual contact with males). Specifically, two questions measuring alcohol use, 10 questions measuring other drug use, and five questions measuring sexual behaviors related to HIV infection were used in the analysis. The final combined data set contained 1,681 records from male students who had sexual contact with males. Reflecting the urbanicity of the sample, $13.6 \%$ of the male students who had sexual contact with males were white, $40.6 \%$ were black, and $45.8 \%$ were Hispanic.

Among male students who had sexual contact with males, black students had a significantly lower prevalence than white students of drinking five or more drinks of alcohol in a row $(22.9 \%$ versus $38.0 \%)$; and ever using inhalants $(21.5 \%$ versus $35.0 \%)$, heroin $(16.5 \%$ versus $29.1 \%$ ), ecstasy ( $19.6 \%$ versus $40.0 \%$ ), or prescription drugs without a doctor's prescription

\footnotetext{
Overall response rate $=$ (number of participating schools/number of eligible sampled schools) $\mathrm{x}$ (number of usable questionnaires/number of eligible students sampled). S http://www.cdc.gov/healthyyouth/data/yrbs/questionnaires.htm.
} 
(31.4\% versus $47.8 \%)$; and drinking alcohol or using drugs before last sexual intercourse (32.6\% versus $72.6 \%$ ) (Table). Black students also had a significantly lower prevalence than Hispanic students of drinking five or more drinks of alcohol in a row $(22.9 \%$ versus $34.5 \%)$ and ever using cocaine $(17.9 \%$ versus $29.3 \%$ ), inhalants ( $21.5 \%$ versus $32.9 \%)$, methamphetamines (18.1\% versus $28.7 \%)$, ecstasy (19.6\% versus $32.1 \%)$, or steroids without a doctor's prescription $(14.9 \%$ versus $25.6 \%$ ).

However, among male students who had sexual contact with males, black students had a significantly higher prevalence than white students of ever having had sexual intercourse $(89.1 \%$ versus $67.4 \%)$ and using a condom during last sexual intercourse (among sexually active students) (47.4\% versus $25.2 \%)$; black students also had a higher prevalence than Hispanic students of ever having sexual intercourse $(89.1 \%$ versus $79.2 \%$ ). No other statistically significant differences in risk behaviors were identified between black male students who had sexual contact with males and white and Hispanic male students who had sexual contact with males.

\section{Discussion}

Black MSM are disproportionally affected by HIV infection. In 2014, the estimated number of new HIV diagnoses among MSM aged 13-24 years was 4,398 among blacks, 1,834 among Hispanics, and 1,366 among whites (1). Although risk

TABLE. Percentage of male high school students who had sexual contact with males, by HIV-related risk behaviors and race/ethnicity 17 large urban school districts, Youth Risk Behavior Surveys, United States, 2009-2013

\begin{tabular}{|c|c|c|c|c|}
\hline Risk behavior & Race/Ethnicity & $\%(\mathrm{Cl})$ & $\begin{array}{l}p \text { value for black \% } \\
\text { versus white } \% *\end{array}$ & $\begin{array}{l}p \text { value for black \% } \\
\text { versus Hispanic \%* }\end{array}$ \\
\hline Current alcohol use ${ }^{\dagger}$ & $\begin{array}{l}\text { Black }^{\S} \\
\text { Hispanic } \\
\text { White }^{\S}\end{array}$ & $\begin{array}{l}49.9(43.0-56.9) \\
50.4(43.5-57.3) \\
61.3(49.8-71.7)\end{array}$ & 0.074 & 0.926 \\
\hline Drank five or more drinks of alcohol in a row & $\begin{array}{l}\text { Black } \\
\text { Hispanic } \\
\text { White }\end{array}$ & $\begin{array}{l}22.9(17.6-29.3) \\
34.5(29.0-40.5) \\
38.0(28.1-49.0)\end{array}$ & $0.017^{*}$ & $0.005^{*}$ \\
\hline Ever used marijuana** & $\begin{array}{l}\text { Black } \\
\text { Hispanic } \\
\text { White }\end{array}$ & $\begin{array}{l}59.6(52.3-66.5) \\
63.0(56.2-69.3) \\
66.6(54.3-76.9)\end{array}$ & 0.320 & 0.502 \\
\hline Current marijuana use ${ }^{\dagger \dagger}$ & $\begin{array}{l}\text { Black } \\
\text { Hispanic } \\
\text { White }\end{array}$ & $\begin{array}{l}32.8(27.0-39.1) \\
35.5(30.4-40.9) \\
41.4(31.6-52.0)\end{array}$ & 0.161 & 0.518 \\
\hline Ever used cocaine ${ }^{\S \S}$ & $\begin{array}{l}\text { Black } \\
\text { Hispanic } \\
\text { White }\end{array}$ & $\begin{array}{l}17.9(13.1-24.1) \\
29.3(24.5-34.6) \\
27.0(18.5-37.5)\end{array}$ & 0.122 & $0.002^{*}$ \\
\hline Ever used inhalants ๆๆ & $\begin{array}{l}\text { Black } \\
\text { Hispanic } \\
\text { White }\end{array}$ & $\begin{array}{l}21.5(15.9-28.3) \\
32.9(27.3-39.0) \\
35.0(24.5-47.1)\end{array}$ & $0.036^{*}$ & $0.008^{*}$ \\
\hline Ever used heroin ${ }^{* * *}$ & $\begin{array}{l}\text { Black } \\
\text { Hispanic } \\
\text { White }\end{array}$ & $\begin{array}{l}16.5(11.9-22.5) \\
22.9(18.1-28.5) \\
29.1(19.3-41.4)\end{array}$ & $0.036^{*}$ & 0.095 \\
\hline Ever used methamphetamines ${ }^{\dagger+\dagger}$ & $\begin{array}{l}\text { Black } \\
\text { Hispanic } \\
\text { White }\end{array}$ & $\begin{array}{l}18.1(13.3-24.1) \\
28.7(23.2-34.9) \\
23.8(15.7-34.4)\end{array}$ & 0.275 & $0.010^{*}$ \\
\hline Ever used ecstasy $§ \S \S$ & $\begin{array}{l}\text { Black } \\
\text { Hispanic } \\
\text { White }\end{array}$ & $\begin{array}{l}19.6(14.3-26.2) \\
32.1(26.6-38.0) \\
40.0(29.7-51.4)\end{array}$ & $0.001^{*}$ & $0.003^{*}$ \\
\hline Ever took steroids without a doctor's prescription ๆๆๆ & $\begin{array}{l}\text { Black } \\
\text { Hispanic } \\
\text { White }\end{array}$ & $\begin{array}{r}14.9(9.3-23.0) \\
25.6(19.7-32.5) \\
21.0(12.4-33.3)\end{array}$ & 0.349 & $0.029 *$ \\
\hline $\begin{array}{l}\text { Ever took prescription drugs without a doctor's } \\
\text { prescription }\end{array}$ & $\begin{array}{l}\text { Black } \\
\text { Hispanic } \\
\text { White }\end{array}$ & $\begin{array}{l}31.4(23.7-40.2) \\
34.3(26.9-42.6) \\
47.8(35.6-60.1)\end{array}$ & $0.035^{*}$ & 0.628 \\
\hline Ever injected any illegal drug ${ }^{\dagger+\dagger \dagger}$ & $\begin{array}{l}\text { Black } \\
\text { Hispanic } \\
\text { White }\end{array}$ & $\begin{array}{l}17.6(11.9-25.1) \\
18.6(14.0-24.2) \\
23.5(14.6-35.5)\end{array}$ & 0.357 & 0.819 \\
\hline
\end{tabular}

See table footnotes on next page. 
Morbidity and Mortality Weekly Report

TABLE. (Continued) Percentage of male high school students who had sexual contact with males, by HIV-related risk behaviors and race/ethnicity -17 large urban school districts, Youth Risk Behavior Surveys, United States, 2009-2013

\begin{tabular}{|c|c|c|c|c|}
\hline Risk behavior & Race/Ethnicity & $\%(\mathrm{Cl})$ & $\begin{array}{l}\mathrm{p} \text { value for black } \% \\
\text { versus white } \% *\end{array}$ & $\begin{array}{l}p \text { value for black \% } \\
\text { versus Hispanic \%* }\end{array}$ \\
\hline Ever had sexual intercourse & $\begin{array}{l}\text { Black } \\
\text { Hispanic } \\
\text { White }\end{array}$ & $\begin{array}{l}89.1(83.0-93.2) \\
79.2(74.1-83.4) \\
67.4(50.1-80.9)\end{array}$ & $0.012^{*}$ & $0.004^{*}$ \\
\hline $\begin{array}{l}\text { Had sexual intercourse with four or more persons } \\
\text { during their life }\end{array}$ & $\begin{array}{l}\text { Black } \\
\text { Hispanic } \\
\text { White }\end{array}$ & $\begin{array}{l}36.0(29.1-43.6) \\
33.6(27.9-39.8) \\
35.4(23.1-50.0)\end{array}$ & 0.940 & 0.608 \\
\hline Currently sexually active $e^{\S \S \S \S}$ & $\begin{array}{l}\text { Black } \\
\text { Hispanic } \\
\text { White }\end{array}$ & $\begin{array}{l}57.2(49.8-64.3) \\
53.5(47.9-58.9) \\
47.3(33.6-61.4)\end{array}$ & 0.234 & 0.423 \\
\hline $\begin{array}{l}\text { Drank alcohol or used drugs before last sexual } \\
\text { intercourse }\end{array}$ & $\begin{array}{l}\text { Black } \\
\text { Hispanic } \\
\text { White }\end{array}$ & $\begin{array}{l}32.6(23.5-43.2) \\
29.2(22.7-36.6) \\
72.6(59.6-82.7)\end{array}$ & $<0.001^{*}$ & 0.577 \\
\hline Condom use during last sexual intercourse & $\begin{array}{l}\text { Black } \\
\text { Hispanic } \\
\text { White }\end{array}$ & $\begin{array}{l}47.4(37.4-57.7) \\
48.8(40.2-57.4) \\
25.2(14.1-40.7)\end{array}$ & $0.011^{*}$ & 0.844 \\
\hline
\end{tabular}

Abbreviation: $\mathrm{Cl}=95 \%$ confidence interval.

* Statistically significant differences at $p<0.05$.

${ }^{\dagger} \mathrm{Had}$ at least one drink of alcohol on at least 1 day during the 30 days before the survey.

$\S$ Non-Hispanic.

"Within a couple of hours on at least 1 day during the 30 days before the survey.

** Used marijuana one or more times during their life.

t+ Used marijuana one or more times during the 30 days before the survey.

$\S \S$ Used any form of cocaine (e.g., powder, crack, or freebase) one or more times during their life.

१ศ Sniffed glue, breathed the contents of aerosol spray cans, or inhaled any paints or sprays to get high one or more times during their life.

*** Used heroin (also called "smack," "junk," or "China White") one or more times during their life.

tt+ Used methamphetamines (also called "speed," "crystal," "crank," or "ice") one or more times during their life.

$\S \S \S$ Used ecstasy (also called "MDMA") one or more times during their life.

१ศศ Took steroid pills or shots without a doctor's prescription one or more times during their life.

**** Took prescription drugs (e.g., Oxycontin, Percocet, Vicodin, codeine, Adderall, Ritalin, or Xanax) without a doctor's prescription one or more times during their life.

t+t+ Used a needle to inject any illegal drug into their body one or more times during their life.

$\S \S \S \S \mathrm{Had}$ sexual intercourse with at least one person during the 3 months before the survey.

กตๆๆ Among students who were currently sexually active.

behaviors are necessary for HIV transmission, the findings in this report do not provide evidence that differences in HIVrelated risk behaviors alone are driving the higher numbers of HIV diagnoses among young black MSM compared with young Hispanic and white MSM. Indeed, black male students who had sexual contact with males in this report often had a lower prevalence of HIV-related risk behaviors.

Other explanations besides differences in HIV-related risk behaviors might help explain differences in HIV diagnoses by race/ethnicity among MSM (2-4). Key among these are higher prevalence of HIV, undiagnosed HIV infection, and other sexually transmitted infections among black MSM compared with MSM of other races/ethnicities. Because black MSM are more likely to have sex partners of the same race, black MSM are at greater risk for HIV infection within their sexual networks. In addition, black MSM who are infected with HIV are less likely to have health insurance, adhere to antiretroviral treatment, and have suppressed HIV viral load. These risks are compounded by social determinants of health associated with increased risk and poorer health outcomes that include higher rates of unemployment and incarceration and lower incomes and educational attainment.

The findings in this report are subject to at least four limitations. First, these data apply only to youths who attend public school and, therefore, are not representative of all persons in this age group. Nationwide in 2014, approximately $8 \%$ of all students enrolled in grades 9-12 were enrolled in a private school (5); in 2009, among persons aged 16-17 years, approximately $4 \%$ were not enrolled in a high school program and had not completed high school (G). MSM might represent a disproportionate percentage of high school dropouts and other youths who are absent from or do not attend school ( 7 ), which might also help explain why racial/ethnic differences in HIV diagnoses are not reflected in racial/ethnic differences in HIVrelated risk behaviors among high school students. Second, these data are representative only of the large urban school districts that included a question in their Youth Risk Behavior Survey on the sex of sexual contacts during 2009-2013 and might not be representative of male students who had sexual contact with males in other urban jurisdictions, in nonurban 


\section{Summary}

What is already known on this topic?

Most new human immunodeficiency virus (HIV) diagnoses among youths occur among males who have sex with males (MSM). Among all MSM, young black males accounted for the largest number of new HIV diagnoses in 2014.

What is added by this report?

The findings in this report do not provide evidence that HIV-related risk behaviors alone drive the higher numbers of HIV diagnoses among young black MSM compared with young Hispanic and white MSM. In fact, young black male students who had sexual contact with males in this report often had a lower prevalence of HIV-related risk behaviors.

What are the implications for public health practice?

Access to comprehensive effective HIV prevention strategies that specifically address not only young black MSM but young MSM of all races/ethnicities is needed to stop the epidemic of HIV infection in the United States.

jurisdictions, in private schools, or nationwide. It is possible that using a different combination of sites would have yielded different results. Third, the extent of underreporting or overreporting of behaviors cannot be determined, although the survey questions demonstrate good test-retest reliability (8). Finally, these analyses are based on cross-sectional surveys and thus can only provide an indication of association, not causality.

To stop the epidemic of HIV infection among young black MSM, increased access to effective programs developed for this population is needed. In March 2015, CDC announced the availability of $\$ 185$ million in funding for 3 years to support a comprehensive approach to HIV prevention among MSM, with an emphasis on males of color. Essential elements of this approach include HIV testing, linkage to and retention in medical care for persons living with HIV, and biomedical and behavioral interventions (including preexposure prophylaxis [PrEP]) to reduce HIV risk. CDC also provides ongoing funding and technical support for school-centered HIV/sexually transmitted disease prevention for young MSM. Schools can facilitate access to youth-friendly health care in schools or via referrals to other youth-serving organizations; provide safe and supportive environments; help improve relationships among students, staff, families, and the community; reduce bullying and harassment; and improve academic achievement.
To be most effective, further research could help to develop practical information and guidance for youths, their families, educators, and pediatricians or other clinicians who care for young people regarding HIV risk assessment, medications and monitoring, medication adherence, parental consent requirements, payment options, and other potential barriers to new prevention and treatment technologies. Reducing HIV infection among young MSM, particularly young black MSM, is key to reducing HIV infection in the United States.

\section{Acknowledgments}

Youth Risk Behavior Survey coordinators in the 17 large urban school districts.

\footnotetext{
${ }^{1}$ Division of Adolescent and School Health, National Center for HIV/AIDS, Viral Hepatitis, STD, and TB Prevention, CDC; ${ }^{2}$ Division of HIV/AIDS Prevention, National Center for HIV/AIDS, Viral Hepatitis, STD, and TB Prevention, CDC; ${ }^{3}$ National Center for HIV/AIDS, Viral Hepatitis, STD, and TB Prevention, CDC.

Corresponding author: Laura Kann, 1kk1@cdc.gov, 404-718-8132.
}

\section{References}

1. CDC. Diagnoses of HIV infection in the United States and dependent areas, 2014. HIV surveillance report 2015; vol. 26. Atlanta, GA: US Department of Health and Human Services, CDC; 2015. http://www. cdc.gov/hiv/library/reports/surveillance/.

2. Millett GA, Peterson JL, Flores SA, et al. Comparisons of disparities and risks of HIV infection in black and other men who have sex with men in Canada, UK, and USA: a meta-analysis. Lancet 2012;380:341-8. http:// dx.doi.org/10.1016/S0140-6736(12)60899-X.

3. Sullivan PS, Rosenberg ES, Sanchez TH, et al. Explaining racial disparities in HIV incidence in black and white men who have sex with men in Atlanta, GA: a prospective observational cohort study. Ann Epidemiol 2015;25:445-54. http://dx.doi.org/10.1016/j.annepidem.2015.03.006.

4. CDC. HIV testing and risk behaviors among gay, bisexual, and other men who have sex with men-United States. MMWR Morb Mortal Wkly Rep 2013;62:958-62.

5. National Center for Education Statistics. Digest of education statistics, 2013. Washington, DC: US Department of Education, National Center for Education Statistics. https://nces.ed.gov/programs/digest/d13/tables/ dt13_105.30.asp.

6. National Center for Education Statistics. Common core of data. Public Elementary/Secondary School Universe Survey. Washington, DC: US Department of Education, National Center for Education Statistics. http://nces.ed.gov/ccd.

7. Burton CM, Marshal MP, Chisolm DJ. School absenteeism and mental health among sexual minority youth and heterosexual youth. J Sch Psychol 2014;52:37-47. http://dx.doi.org/10.1016/j.jsp.2013.12.001.

8. Brener ND, Kann L, McManus T, Kinchen SA, Sundberg EC, Ross JG. Reliability of the 1999 youth risk behavior survey questionnaire. J Adolesc Health 2002;31:336-42. http://dx.doi.org/10.1016/ S1054-139X(02)00339-7. 